\title{
COVID-19 and Pornography Traffic in Spain: How to Prevent the Social Effects of its Consumption in Families.
}

Carmen Orte*, Lluís Ballester* \& Lluc Nevot-Caldentey*+

*Universitat de les Illes Balears (UIB), Departamento de pedagogía y didácticas específicas. Grupo de Investigación y Formación Educativa y Social (GIFES), Laboratorio de Investigación sobre Familia y Modalidades de Convivencia (LIFAC), Palma de Mallorca.

+ Ctra Valldemossa, km 7.5, 07122; Palma de Mallorca, Islas Baleares, Spain; Tel. (00 34) 971172583; lluc.nevot@uib.es 


\section{Introduction}

In November and December 2019, the first cases of "2019 novel coronavirus pneumonia (n-CoV)" in Wuhan triggered a worldwide pandemic of the virus, which in January came to be named "severe acute respiratory syndrome coronavirus 2 (SARSCoV-2) by the Chinese Center for Disease Control \& Prevention (CCDC). In barely two months, it led to a world health crisis (Li et al., 2020).

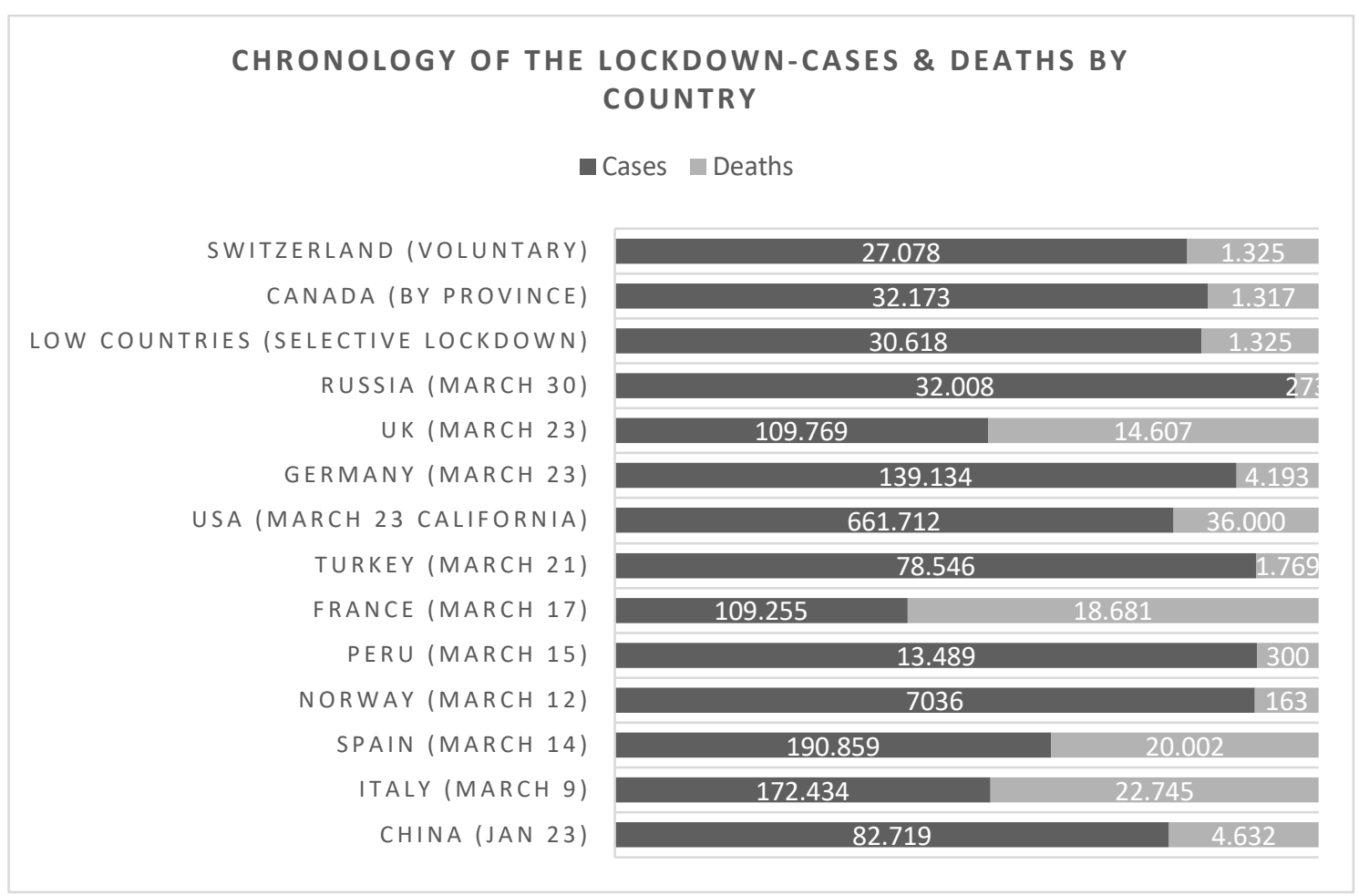

Over 2.2 million people worldwide have become infected as a result of the pandemic (Spanish Ministry for Health, 2020; RTVE, 2020). 35 days into the Spanish lockdown, Spain had 191,726 cases. This made it the country with the second highest number of confirmed cases of COVID-19 after the United States, with a figure of 661,712 (data from the Spanish Ministry of Health, consulted at 7 a.m. on 18/04/2020).
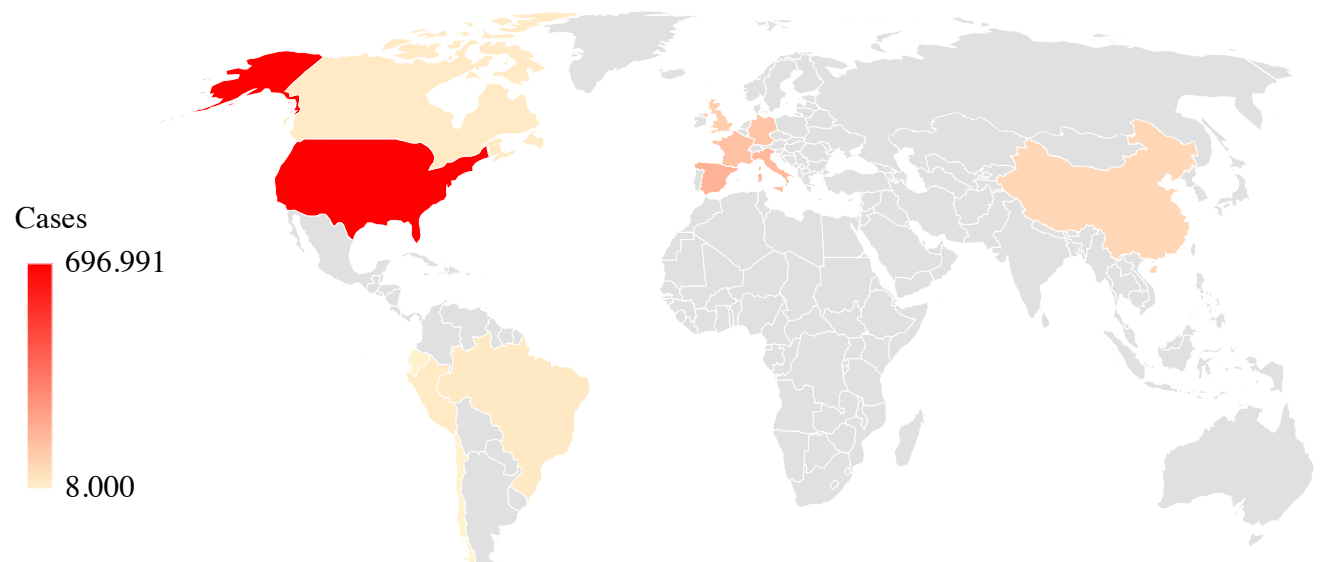
The world health crisis has sparked off a social crisis, some of whose outcomes are now observable, as also occurred with previous pandemics. The SARS, Ebola or H1N1 outbreaks demonstrated that confinement is the cause of post-traumatic stress, depression and insomnia, among other mental health problems, in addition to negative emotions like sadness, fear, guilt or nervousness. These effects can last for up to three years from the end of movement restrictions (Bidegintza, Opik, Universitat Pompeu Fabra \& CISAL, 2020, Orte, Sánchez-Prieto, Vives, 2020).

In parallel with this, high levels of family stress brought about by the lockdown can contribute to unhealthy coping strategies, boosting the potential risk of negative outcomes (Ducy \& Stough, 2011). There has already been evidence of an increase in gender-based violence since the outbreak of the virus (Fisher, 2020; Orte, Ballester \& Nevot, 2020).

Data on the consumption and spread of pornography shows that there has been an upward trend. At the same time, organizations like the UN, Save the Children and UNICEF warn of an increase in child violence and in the sale, trafficking, exploitation and sexual abuse of children during the lockdown (UN News, 2020; Save the Children; UNICEF), with an exponential rise in sex crimes (RCEW, 2020; The Office for National Statistics [ONS], 2020; Council of Europe Portal, 2020).

The porn industry is taking advantage of the lockdown to boost the strategies it uses to attract customers, encouraging and directing online traffic to its websites. This has led to the closure of some entertainment businesses unable to deal with the competition of explicit porn ads in the columns of web pages (Chortle, 2020). Taking advantage of the wage problems of workers from certain sectors, websites like Is My Girl claim that it is possible to earn over 100,000 dollars by featuring in its pornographic content. Efforts are also being made to attract broader audiences through free adult movie services with the tagline "scenes of violence to women not allowed" in a model that prevents under-age access (Martínez, 2020), giving the impression that these free services are a philanthropic initiative for COVID-19 victims or for those in confinement.

These highly effective marketing strategies have allowed the industry to expand while trying to divert attention from criticisms of its effects and health-related and social risks. Different organizations have called for urgent measures to be taken to stop videos of female rape, submission and suffering and videos of child sexual abuse (UNICEF, 2020; ONU, 2020; HuffingtonPost, 2020; Crónica Global, 2020; CNBC, 2020), in addition to demanding the closure of Pornhub (in a petition by 350,000 people) due to the publication of non-consensual videos (Isaacs (2020) which may have been facilitated by increased sexting during the lockdown. According to a survey by sexplace.es, based on a Spanish sample, $60 \%$ of all Spanish people have engaged in sexting and $68 \%$ have taken part in some kind of erotic online game in the last few days (Fernández, 2020). The campaign NotYourPorn\# is one example of various initiatives to support pornography victims. 


\section{World}

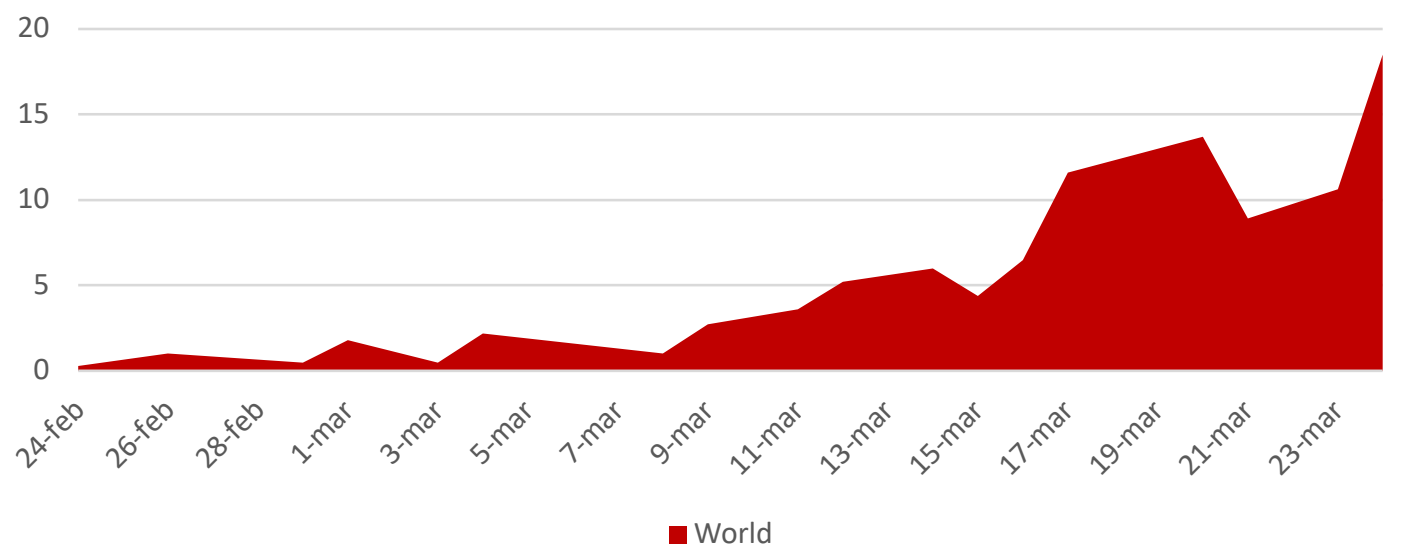

Although over-average world Internet porn traffic has been observable since February $24^{\text {th }}$, the most glaring new trend began on March $10^{\text {th }}$, with a $13.7 \%$ rise in traffic being achieved by March $20^{\text {th }}$. On March $24^{\text {th }}$, however, there was a massive rise of $18.5 \%$ with the launch of a free Premium service by Pornhub, the world's biggest pornographic website with over 42 thousand million visits in 2019 and over 115 million visits a day. Over the last 30 days, over nine million searches with the word "coronavirus" have been made on the website, with hits of over 1,000 related videos (Lehmiller, 2020; Spratt, 2020; Pornhub, 2020). By March $27^{\text {th }}$, online porn sites were receiving more visits than Netflix, Amazon and Twitter together (Christian Concern, 2020).

According to data published by Pornhub-the porn website mentioned above which offers free Premium accounts during the lockdown-, Spain accounted for the highest growth in the website's international traffic, peaking at $61 \%$, fifty points higher than the world maximum of $11.6 \%$ (Pornhub, 2020; HuffingtonPost, 2020).

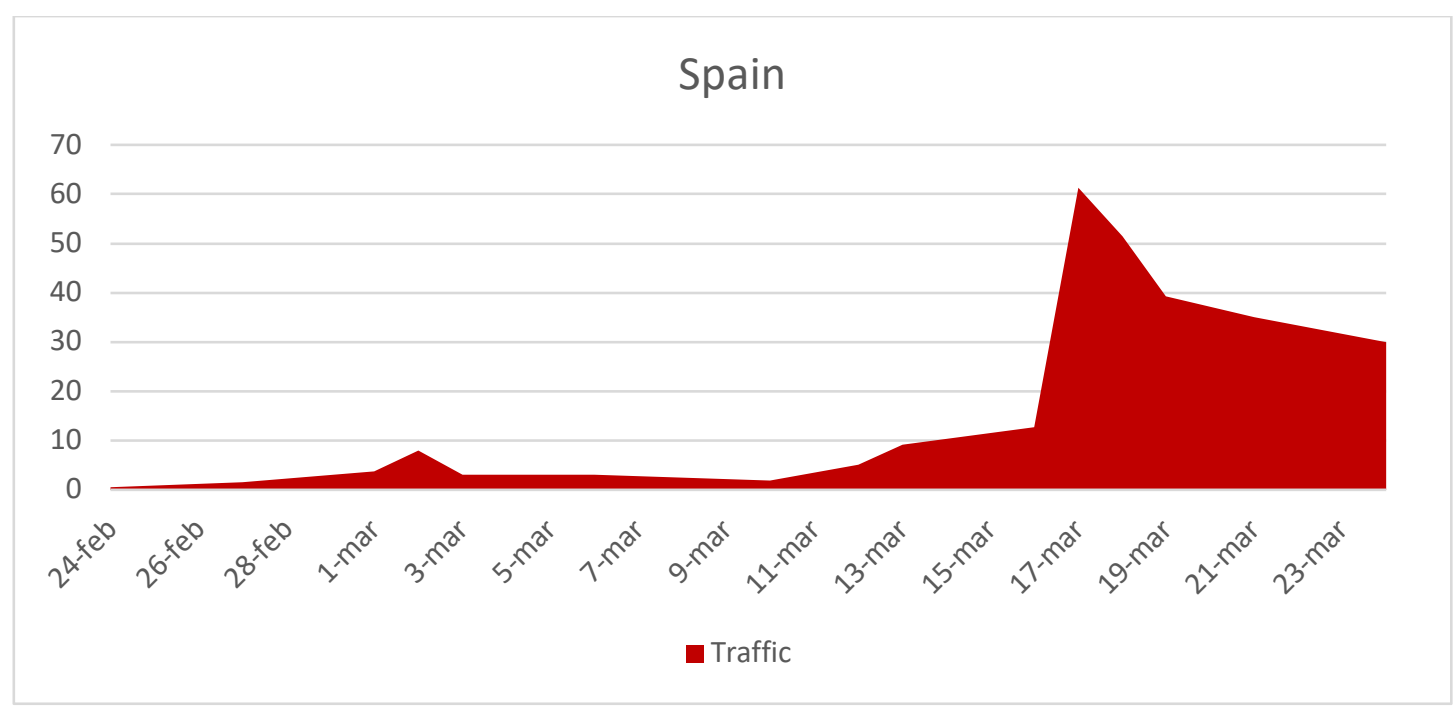


From a selection of news items published between February $12^{\text {th }}$ and April $10^{\text {th }}$, a chronological outline is shown below of the main problems that have emerged in relation to the said traffic:

- On February $12^{\text {th }}$, the US National Center for Missing \& Exploited Children identified over 25,000 cases of child pornography uploaded in India (THE ECONOMIC TIMES, 2020).

- By March $6^{\text {th }}$, China had enforced online restrictions to stamp out pornographic content as a preventive measure during the quarantine (FOREIGN POLICY, 2020).

- On March 12 $2^{\text {th }}$ Pornhub advertised a special offer available through to April $3^{\text {rd: }}$ "To help you during these weeks at home, for the whole month, you can access Pornhub Premium free of charge, with no need to use your credit card" (THE SUN, 2020).

- By March $23^{\text {rd }}$, there had been an $11.6 \%$ growth in porn traffic, with 8 million searches using the world "coronavirus" and hits of over 1,000 resulting videos (PSYCHOLOGY TODAY, 2020).

- On March 24 ${ }^{\text {th }}$, the NATIONAL REVIEW (2020) published the testimonials of a Reddit Forum featuring over half a million people in the process of overcoming an addiction to pornography. The testimonials describe relapses along the lines of: "This corona $s^{* * *}$ is killing me. Not the virus but the quarantine. I went to the gym every day and I was very active in my social life but now I have nowhere to go and nothing to do. I relapsed after 24 days." (Testimonial 1); "Today I relapsed 3 times, when in the past normal weeks I used to relapse 1 or 2 times. Need help, this can get much worse if I don't stop it now." (Testimonial 2); "I already relapsed 9 times this month." (Testimonial 3).

- On March 25 ${ }^{\text {th }}$, CHORTLE (2020) warned of the closure of some entertainment businesses due to the high volume of spectators who choose to consume products from the extremely explicit X-rated ads. that accompany searches. On the same day, M.P.s and activists repeated the need to take urgent measures to prevent videos of serious acts like rape, incest, child abuse and people trafficking from being uploaded onto mainstream porn sites by anonymous users (THE GUARDIAN, 2020).

- On March $27^{\text {th }}$, the media warned of the increase in the number of companies that vet their employees' activities during the lockdown, alerted by the consumption of pornography on work devices. Online porn sites were receiving more visits than Netflix, Amazon and Twitter together (CHRISTIAN CONCERN, 2020; VICE, 2020).

- Computer hackers are taking advantage of the time people spend in front of a screen working from home or visiting porn sites to seize, copy and disseminate media data and content from personal and private computers and other devices. The newspaper THE SUN (2020) noted that porn is a favourite tool for hackers.

- On March 31 ${ }^{\text {st }}$, THE ONION (2020) warned of the different risks faced by young people who consume pornography during the lockdown, such as monetary enticements by the porn industry for people who have lost their jobs.

- On April $2^{\text {nd }}$, Vivex.tv, a Spanish porn site, announced that it would be reopening free of charge during the lockdown to "offer adult movies, protected from child viewing, in order to uphold porn's place as a film genre" (EL MUNDO, 2020).

- On April $3^{\text {rd }}$, PRENSA GRÁFICA (2020) stated that there had been a 25\% increase in connections to the Internet to download paedophilic material in Spain.

- On April 5 $5^{\text {th }}$ AXIOS (2020) claimed that United States citizens' worst habits were being doubled in response to stress due to the pandemic. 
- On April 6 ${ }^{\text {th }}$, there was said to be a $95 \%$ increase in porn consumption in India (data for March 27 $7^{\text {th }}$ ( NEWS18, 2020). Some erotic novels adapted to lockdown scenarios were published, like "Covid-69": "You can't write traditional erotica now because it wouldn't ring true. There are no chance encounters any more. The plumber doesn't come to visit. Your personal trainer has to stay two metres from you. Your babysitter has been declared nonessential. Your child's teacher now gives you feedback solely through Google Classroom. Erotica has to adapt, or it will die." (THE GUARDIAN, 2020).

- ICTFRAME (2020) published a series of tips for parents on April $10^{\text {th }}$ to prevent children from finding and watching porn during the lockdown due to the effects that it might have.

\section{The consequences of porn consumption}

Aside from the social problems that the lockdown has caused, the increase in porn consumption is a real cause for concern since pornography legitimizes acts of gender violence which would ordinarily be prohibited (e.g. rape, physical aggression and group penetration), cultivating contempt, abuse and violence. The same is true of child sexual abuse, by legitimizing an erotic model of paedophilic sex (De Miguel, 2020).

Indeed, the categories with the highest number of videos on Pornhub are "adolescents" with 268,105 million videos, "amateur" with 303,779 million, "anal" with 125,167 million and MILF [Mother/Mom/Mama I'd Like to Fuck] with 137,946 million videos.

Past technological developments are closely associated with today's new forms of pornography (Ballester \& Orte, 2019). Future developments, like the "Internet of the senses", will change forms of online consumption over the forthcoming decade. (In the first chapter of the series "Black Mirror", an approximate idea is given of the sensations that it will involve). The online digital world will be opened up to encompass our senses of taste, smell and touch, thanks to the expansion of virtual and augmented reality, artificial intelligence, automatization and 5G (Bello, 2020). The shortcomings of having to view quasi-real experiences through a screen have been suppressed-that is, all the physical and social barriers that porn consumption involved up until very recently-, and those rough edges will continue to be polished.

Many youths and adolescents learn about sexuality through pornography, a potential educational vehicle perfectly suited to the ways in which the brain processes meaningful learning experiences (DeKeserdy, 2015).

Pornography does not convey the side to sexuality that is associated with forging a bond, responding to your partner's sexual preferences or needs, or with physical and affective contact (Bridges et al., 2010). Neither does it reflect the possible consequences of sex: STDs, unplanned pregnancies, cervical cancer, intestinal parasites, bruises etc. In fact, in nine out of every ten pornographic scenes, the women are subject to some kind of aggression in the form of knocks or blows, shouting or gestures (Bridges et al., 2010; Frith, 2014). This is a serious issue, in terms of health and wellbeing, given the social and psychological repercussions of not having a sex education that takes into account affective aspects. These repercussions can range from the normalization of risky sexual practices to violent sexual behaviours, many copied from porn scenes (Ballester \& Orte, 2019; Perry, 2019). Unintentionally or not, most adolescents get part of their sex 
education from pornography (Morgan, 2011; Peter \& Valkenburg, 2016; Comunión, 2019; WHO, 2020).

Pornography is designed for men, and its impact on men and women differs. $75 \%$ of all pornography is consumed by men and $25 \%$ is declared to be consumed by women (20.5 million women). Male consumption of pornography tends to be viewed as normal, while there is the unhealthy belief that women do not watch it, as if they ought to boost their consumption for feminist reasons (DeKeserdy, 2015).

Girls, in particular, learn that their social acceptance and value is related to their sexuality, generally in association with developed symptoms of depression, anxiety and a negative self-body image. They learn to believe that their bodies are intrinsically sexy and that they are a kind of currency. They learn to use diet to change their physical makeup and other techniques, such as makeup or the way they dress, to modify other physical variables. Most importantly, they come to believe that their personalities are not as important as their bodies. Pornography can be regarded as a vehicle for misogyny and violence ( $90 \%$ of the scenes feature violence to women or shaming) and so girls that consume pornography are more likely to have a low self-esteem (Ever Accountable, 2020).

Persistent evidence of sexual inequality led to the development of the feminist movement; a pressure group intent on changing this scenario and working toward civil equality. This might raise the question "why does one faction of the movement devote so much political energy to banning pornography?" when compared with so many other issues, such as abortion or the defence of mechanisms to promote female equality in the political and employment worlds, both of which seem to be more pertinent issues in the search for sexual equality. For feminists who advocate censure, this is because those very evident, supposedly bigger problems are actually related to pornography and derived from it. Social inequalities are observable in public spheres like politics or economics, but they are actually spawned in private, more intimate circles, such as sexual ones (Larissa COSTA; Fabiola ROHDEN, 2016).

We share the feminist movement's beliefs that sexuality lies at the roots of inequality. Although feminists who disagree with anti-pornography laws claim that "pornography has some social functions that benefit women", they do not deny the urgent need to gain a better insight into the problem in order to review and reflect on feminist arguments. The damage attributed to pornography goes beyond mere disgust at the portrayal of women as objects. It is seen as a more important vehicle in the systematic reproduction of gender inequalities, as an acute expression of how to condition the way in which women are perceived socially. Thus censorship of pornography would represent a qualitative step forward in democracy and it should be fostered by a political system that pays equal regard to men and women (CASARIN, 2016).

\section{Strategies to prevent the effects of pornography}

Porn consumption among adults can be prevented or reverted in different ways. Audrey (2020), Fight the New Drug (2020) and Rube (2019) offer some recommendations, all along the lines of maximizing the benefits of a life with rich social and family ties, as well as promoting healthy leisure and recreational activities like physical exercise, meditation, voluntary work, reading or cooking. The idea is to fill one's 
time with hobbies and personal interests that contribute to personal growth and development. Boredom and anxiety should be avoided by finding distractions, by getting to know other people and thus cultivating interpersonal environments and sexuality, and by cultivating intrapersonal ones through imagination as a source of sexual stimulus. A low or negative self-image must be avoided by fostering a strong sense of self-esteem. In short, porn-free activities must be promoted.

Pornography can be prevented among youths and adolescents by fostering family relational skills, developed through initiatives like the Family Competence Programme. This encourages family relations based on positive communication, affectivity and family rules, among other skills, in order to strengthen family ties. In this way, youths and adolescents forge stronger affective ties, they gain a better understanding of how to take assertive decisions and they learn to cope with adolescent risks (Ballester et al, 2018; Orte \& Ballester, 2019). Family engagement is fundamental for these programmes to be effective (Nevot-Caldentey, Orte \& Ballester, 2019; Nevot, Ballester \& Vives, 2018).

Tackling youth and adolescent worries and concerns can be a solid base for fostering better family practices. Family planning should be dealt with early on in everyday interactions (Sexual Assault, 2020).

\section{Conclusions}

There is a clear increase in porn consumption in situations of confinement and/or social isolation, particularly in crisis scenarios. However, this is the first crisis to occur in a context of new online pornography, a phenomenon recently described in a study by Ballester \& Orte in 2019, hence the exponential growth in traffic and the multitude of new offers targeted at all kinds of consumers. Although there can be multiple different online risks in times of confinement, like all crises, the COVID-19 pandemic is also an opportunity to try and achieve greater levels of freedom, an improved sense of personal wellbeing and improved relations with those around one.

In the case of youths and adolescents, who now have more time to be online, family supervision is essential. Parents' active involvement in their children's affective sex education will boost their parental capacity to respond to problems that arise from the children's online interactions. This is the best moment to tackle this issue as a family.

In the case of adults, a growing awareness of what porn consumption entails is the first step in controlling it and starting to learn new skills, seeking satisfaction in new everyday routines that can be built up during the lockdown through a life of rich engagement with others and through leisure activities that can be used to offset boredom and anxiety. 


\section{Bibliography}

Audrey, E. (2020). The awesomeness list! 101 things to do instead of look at pornography. Available on https://everaccountable.com/blog/the-awesomeness-list101-things-to-do-instead-of-look-at-pornography/

Ballester, L., Valero, M., Orte, C. \& Amer, J. (2018). An analysis of family dynamics: a selective substance abuse prevention programme for adolescents. European Journal of Social Work. 10.1080/13691457.2018.1473842

Barr, E.M., Goldfarb, E.S., Russell, S., Seabert, D., Michelewallen, M., Wilson, K.L., (2014) Improving Sexuality Education: The Development of Teacher Preparation Standards. Journal of School Health, 84(6), 396-415.

Bello, E. (2020). Internet de los sentidos: qué es y cómo cambiará nuestra vida. Available on https://www.iebschool.com/blog/internet-de-los-sentidos-tecnologia/

Benusan, H. (2004). Observações sobre a libido colonizada: tentando pensar ao largo do patriarcado". Revista Estudos Feministas, 12(1), 360.

Bidegintza, Opik, Universitat Pompeu Fabra \& CISAL (2020). Estudio sobre confinamiento y salud en población infantil: ¿tiene la desigualdad social impacto en las condiciones en las que la población infantil está confinada y en su salud? Available on https://www.ehu.eus/documents/3638427/14308653/EstudioConfinamiento-y-Salud-OPIK-Encuesta.pdf/2b6a5600-af28-761e-7bbd$77544 d a 65 c 6 a$

Bridges, A. J., Wosnitzer, R., Scharrer, E., Sun, C. \& Liberman, R. (2010). Aggression and Sexual Behavior in Best Selling Pornography Videos: A Content Analysis Update. Violence Against Women, 16(10), 10651085. doi:10.1177/1077801210382866

Casarin, J. C. (2016). Libertade de expressão, pornografia e igualdade de gênero. Revista Estudos feministas, 21(1). Available on https://doi.org/10.1590/S0104026X2013000100008

Chortle (2020). How porn is helping the comedy industry during lockdown. Available on $\quad$ https://www.chortle.co.uk/punchingups/2020/03/25/45729/how_porn is_helping the comedy_industry_during_lockdo $\underline{\mathrm{wn}}$

Costa, L. \& Rohden, F. (2016). Entre o obsceno e o científico: pornografia, sexologia e a materialidade do sexo. Estudios feministas magazine, 24(3). Available on http://dx.doi.org/10.1590/1806-9584-2016v24n3p715

Council of Europe Portal (2020). Protecting and empowering children during the Covid-19 pandemic. Available on https://www.coe.int/en/web/children/covid-19

DeKeseredy, W. (2015). Critical Criminological Understandings of Adult Pornography and Women Abuse: New Progressive Directions in Research and Theory. International Journal for Crime, Justice, and Social Democracy, 4(4) 421. doi:10.5204/ijcjsd.v4i4.184

Fisher, S. (2020). Virus vices take a toll on Americans. Available on https://www.axios.com/coronavirus-vices-alcohol-marijuana-food-23f02d5e-b82b4944-8609-b4479af1070e.html

Frith, H. (2014). Visualizing the 'real' and the 'fake': emotion work and the representation of orgasms in pornography and everyday sexual interactions. Journal of Gender Studies, 24(4), 386-398. doi:10.1080/09589236.2014.950556

Grubbs, J.B., Wright, P.J., Braden, A.L., Wilt, J.A. \& Kraus, S.W. (2019) Internet pornography use and sexual motivation: a systematic review and integration, Annals 
of the International Communication Association, 43:2, 117-155, DOI: 10.1080/23808985.2019.1584045

Lehmiller, J. (2020). How the pandemic is changing pornography. Available on https://www.psychologytoday.com/us/blog/the-myths-sex/202003/how-thepandemic-is-changing-pornography

Martínez, L. (2020). El porno español renace con el confinamiento por el coronavirus. Available on https://www.elmundo.es/cultura/cine/2020/04/02/5e84ae9f21efa0150f8b458a.html

Spanish Ministry of Health (2020). Update no. 79. Enfermedad por el coronavirus. Available on https://www.mscbs.gob.es/profesionales/saludPublica/ccayes/alertasActual/nCovChina/documentos/Actualizacion 79 COVID-19.pdf

Morgan, E. M. (2011). Associations between Young Adults' Use of Sexually Explicit Materials and Their Sexual Preferences, Behaviors, and Satisfaction. Journal of Sex Research, 48(6), 520-530. doi:10.1080/00224499.2010.543960

Nevot-Caldentey, Ll., Orte, C. \& Ballester, Ll. (2019). Strategies for family engagement in evidence-based programmes: A meta-synthesis of systematic reviews from a social casework approach. Social Work and Social Sciences Review, 1280(12), 47-64.

Nevot, L. Ballester, L. \& Vives, M. (2018) La implicación parental en los programas de competencia familiar: una revisión sistemática exploratoria, in Roig-Vila, R. (ed), El Compromiso Académico y Social a través de la Investigación e Innovación Educativas en la Enseñanza Superior. Barcelona: Editorial Octaedro

Orte, C., Ballester, L. \& Nevot-Caldentey, L. (2020). Family support against covid19. Available on https://doi.org/10.1590/SciELOPreprints.297

Perry, S. L. (2019). Is the link between pornography use and relational happiness really more about masturbation? Results from two national surveys. The Journal of Sex Research, 0,1-13. doi:10.1080/00224499.2018.1556772

Peter, J. \& Valkenburg, P. M. (2016). Adolescents and Pornography: A Review of 20 Years of Research. Journal of Sex Research, 53(4-5), 509531. doi:10.1080/00224499.2016.1143441

Pornhub (2020). Coronavirus update - March 25th. Available on https://www.pornhub.com/insights/coronavirus-update

Rube, T. (2019). How to substitute pornography. Available on https://www.wikihow.com/Substitute-Pornography

Save the Children (2020). Interim technical note: protection from sexual exploitation and abuse (PSEA) during COVID-19 response. Available on https://resourcecentre.savethechildren.net/library/interim-technical-note-protectionsexual-exploitation-and-abuse-psea-during-covid-19

Sexual Assault (2020). Start at home: modeling healthy behaviors keeps kids safe. Available on https://medium.com/sexual-assault-awareness-month-2020/start-athome-modeling-healthy-behaviors-keeps-kids-safe-f454b929a2a0

Spratt, A. (2020). Porn use is up, thanks to the pandemic. Available on https://theconversation.com/porn-use-is-up-thanks-to-the-pandemic-134972

UN News (2020). Online predators put millions of children at risk during COVID-19 pandemic lockdown. Available on https://news.un.org/en/story/2020/04/1061742 
UNICEF (2020). No dejemos que los niños sean las víctimas ocultas de la pandemia de COVID-19. Available on https://www.unicef.org/es/comunicados-prensa/nodejemos-ninos-sean-victimas-ocultas-de-la-pandemia-covid-19

World Health Organization (WHO), (2020). Report on global sexually transmitted infection surveillance. Available

https://apps.who.int/iris/bitstream/handle/10665/277258/9789241565691-

eng.pdf?ua $=1$ 